\title{
Enforced effect of tk-MCP-1 fusion gene in ovarian cancer
}

\author{
Shuhui Hong ${ }^{1,2+}$, Ping Zhang ${ }^{1,3+}$, Hui Zhang ${ }^{1}$, Lin Jia ${ }^{1}$, Xun Qu ${ }^{4}$, Qifeng Yang ${ }^{5}$, Fengnian Rong ${ }^{2^{*}}$ and Beihua Kong ${ }^{1 *}$
}

\begin{abstract}
Objective: The efficiency of HSV-tk/GCV system is not high because of insufficient gene transfer and incompletely initiative of host antineoplastic potency. The present study was designed to assess the antitumor efficacy of tk-MCP-1 on ovarian cancer in vitro and vivo.

Methods: A novel bicistronic expression system can help to improve the expression level of a gene in a stable manner. pLXSN/tk-MCP-1 co-expressing tk and MCP-1 genes was constructed using a pLXSN retroviral vector and an internal ribosome entry site sequence by restriction enzyme. Western blot was performed to determine tk and MCP-1 expression in the infected $\mathrm{SKOV}_{3}$. The GCV-sensitively tumoricidal activities of SKOV 3 /tk-MCP-1 with or without monocytes were compared to those of $\mathrm{SKOV}_{3}$ expressing HSV-tk or MCP-1. We investigated the growth of subcutaneous tumors in SCID mice immuno-reconstituted, and evaluated the antitumor effect of MCP-1 in conjunction with suicide gene.
\end{abstract}

Results: The significant GCV-sensitively tumoricidal activity of pLXSN/tk-MCP-1 was observed when compared with those of pLXSN/tk, pLXSN/MCP-1 and pLXSN/neo, especially when monocytes were added. The growth of subcutaneous tumors in SCID mice immuno-reconstituted was markedly suppressed by co-delivery of HSV-tk and MCP-1 genes, and the enhanced antitumor effect was associated with the recruitment of monocytes.

Conclusion: These results demonstrated pLXSN/tk-MCP-1 presented an enhanced antitumor effects on ovarian cancer by orchestration of immune responses.

Keywords: Herpes simplex virus thymidine kinase, Monocyte chemoattractant protein-1, Gene therapy, Ovarian neoplasma, SCID

\section{Background}

Ovarian cancer is the leading cause of death from gynecologic cancers. Every year, approximately 200,000 women are diagnosed with ovarian cancer and more than 100,000 women died of ovarian cancer around the world $[1,2]$. Due to inherent and acquired chemoresistance of ovarian cancer, the effect of current therapies for advanced or metastatic ovarian cancer is far from satisfying [3]. This underscores the imperative to adopt new strategies to fight against ovarian cancer effectively.

\footnotetext{
*Correspondence: fnrong@163.com; kongbeihua@sdu.edu.cn

${ }^{\dagger}$ Equal contributors

'Department of Obstetrics and Gynecology, Qilu Hospital, Shandong University, 107 Wenhuaxi Road, Ji'nan 250012, People's Republic of China ${ }^{2}$ Department of Obstetrics and Gynecology, Affiliated Qianfoshan Hospital of Shandong University, 16766 Jingshi Road, Ji'nan 250014, People's Republic of China

Full list of author information is available at the end of the article
}

Suicide gene therapy is one of these strategies with antitumor effect $[4,5]$. However, its efficacy for the treatment of cancer is limited because of the insufficient gene transfection and insufficient induction of host immunity [6-8] .

The bystander killing effect is a mechanism counting on host immunological function, which could kill the neighboring uninfected tumor cells produced by suicide gene HSV-tk/GCV system and finally strongly enhance the capacity against the tumor cells $[9,10]$. Recently, increasing studies have been carried out to optimize the suicide gene therapy in combination with immune genes.

MCP-1 is one of thte chemokine responsible for the recruitment and activation of mononuclear cells, and it can induce nonspecific and specific antitumor immunity $[11,12]$. Therefore, we hypothesized that tk-MCP-1 fusion gene could significantly enhance the efficacy of suicide gene

\section{Biomed Central}


therapy contributed by the direct antitumor activity and the elicited anti-tumor immunity in ovarian cancer.

\section{Materials and methods}

\section{Recombinant retroviruses}

We designed the PCR or RT-PCR primers for HSV-tk, MCP-1 and IRES. HSV-tk: 5'-GCGCGTATGGCTTCG TACCC-3' and 5'-TCCTTGCGTGTTTCAGTTAGTC-3'. MCP-1: 5'-CGGAATTCATATGCAGCCAGATGCAATC-3' and $5^{\prime}$-CGGGATCCTTA TCAAGTCTTCGGAGT-3'. IRES: 5' - CGATCGATCTCCACGTGGCGGC-3' ${ }^{\prime}$ and 5' - CCTGA TAATCCAATTCGCTTTAT-3'. Total RNA was extracted from human peripheral blood mononuclear cells (PBMC) followed by RT-PCR to generate MCP-1 gene fragment with $5 \mathrm{~min}$ at $95^{\circ} \mathrm{C}, 1 \mathrm{~min}$ at $94^{\circ} \mathrm{C}, 1 \mathrm{~min}$ at $58^{\circ} \mathrm{C}$ and 1 min at $72^{\circ} \mathrm{C}$, up to 35 cycles. By Restriction Enzyme cutting site, EcoRI - XhoI internal ribozyme entry site (IRES) fragment of poliomyelitis virus, we got linear pLXSN. Then it was inserted into the herpes simplex virus thymidine kinase gene fragment from pWZLneotkglyCD with BamHI-EcoRI to generate the tk-IRES-neo, and $\mathrm{pLXSN} / \mathrm{tk}$ was obtained by insertion of tk-IRES-neo into Linear pLXSN. pLXSN fragment combined with MCP-1 gene fragment to generate $\mathrm{pLXSN} / \mathrm{MCP}-1$. MCP-1 gene fragment was inserted into pLXSN/tk-IRES-neo to form $\mathrm{pLXSN} / \mathrm{tk}-\mathrm{MCP}-1$. The above plasmids were verified by PCR. Retroviruses containing $\mathrm{pLXSN} / \mathrm{tk}$ MCP-1, pLXSN/tk, pLXSN/MCP-1 and pLXSN/neo respectively were generated by transfecting PA317 cells using liposome, and transfected cells were selected by G418 at diverse concentrations. The titer of retrovirus was determined (Figure 1-A).

\section{RT-PCR}

Total RNA was extracted as described previously and RT-PCR was performed comprising 33 thermal cycles of $95^{\circ} \mathrm{C}$ for $5 \mathrm{~min}, 94^{\circ} \mathrm{C}$ for $1 \mathrm{~min}, 58^{\circ} \mathrm{C}$ for $1 \mathrm{~min}, 72^{\circ} \mathrm{C}$ for $1 \mathrm{~min}$ and $72^{\circ} \mathrm{C}$ for $7 \mathrm{~min}$. The same condition was used in MCP-1 amplification except 30 cycles in total.

\section{Cell culture and retrovirus infection}

The human epithelial ovarian cancer cell line $\mathrm{SKOV}_{3}$ was used in vitro and vivo. $\mathrm{SKOV}_{3}$ cells were infected with supernatant of retrovirus at high titre containing $\mathrm{pLXSN} /$ tk-MCP-1 $\left(5.3 \times 10^{5} \mathrm{CFU} / \mathrm{ml}\right), \mathrm{pLXSN} / \mathrm{tk}\left(6.0 \times 10^{5} \mathrm{CFU} /\right.$ $\mathrm{ml}), \mathrm{pLXSN} / \mathrm{MCP}-1\left(4.8 \times 10^{5} \mathrm{CFU} / \mathrm{ml}\right)$ and $\mathrm{pLXSN} /$ neo $\left(4.5 \times 10^{5} \mathrm{CFU} / \mathrm{ml}\right)$ at various volumes $(100 \mu \mathrm{l}, 200 \mu \mathrm{l}$, $500 \mu \mathrm{l}$ or $1 \mathrm{ml}$ ), supplied with RPMI-1640 with $10 \%$ NBS to $2 \mathrm{ml}$, and then added polybrene (the concentration of polybrene at $8 \mu \mathrm{g} / \mathrm{ml}$ ). Three hours later, cells were supplied with RPMI-1640 with $10 \%$ NBS to $8 \mathrm{ml}$ and cultured for $2-3$ days at $37^{\circ} \mathrm{C}$ in a $5 \% \mathrm{CO}_{2}$ atmosphere. G418 at $600 \mu \mathrm{g} / \mathrm{ml}$ was added into 4 kinds of cells. Ten days later, cells which survived in medium containing
G418 at $600 \mu \mathrm{g} / \mathrm{ml}$ named $\mathrm{SKOV}_{3} / \mathrm{tk}-\mathrm{MCP}-1, \mathrm{SKOV}_{3} / \mathrm{tk}$, $\mathrm{SKOV}_{3} / \mathrm{MCP}-1$ and $\mathrm{SKOV}_{3} /$ neo.

\section{Western blot}

Proteins were extracted using protein extraction reagent, $48 \mathrm{~h}$ after transfection and save at $-20^{\circ} \mathrm{C}$, following a protocol provided by the manufacture. MCP-1 protein and tk protein expressions were detected with western blot. Proteins with equal amount were separated by appropriate concentration SDS-polyacrylamide gel electrophoresis and transferred onto PVDF membrane (Millipore, Billeriaca, MA, USA). The membranes were blocked in TBST for $1 \mathrm{~h}$ at room temperature and then incubated with primary antibodies fo tk (1:500, Abcam, United Kingdom), MCP-1 (1:500, Santa Cruz Biotechnology) and $\beta$-actin (1:5000, Boston, $\mathrm{MA}$ ) overnight at $4^{\circ} \mathrm{C}$ The membranes were then washed three times with TBST, followed by incubating with HRP-labeled secondary antibodies (KPL, Gaithersburg, MD, USA) (1:5000). Bound antibody was visualized using ECL detection reagent (Merck, Darmstadt, Germany).

\section{Antitumor effect of GCV}

The number of viable cells were determined by 3-(4, 5-dimethylthiazol-2-yl) -2,5-diphenyl tetrazolium bromide (MTT) assay. There were 4 experimental groups including $\mathrm{SKOV}_{3} /$ tk, SKOV 3 /MCP-1, SKOV 3 /tk-MCP-1 and SKOV 3 / neo. Cells were re-suspended in fresh culture medium at the density of $2 \times 10^{4}$ cells $/ \mathrm{ml}, 180 \mu \mathrm{l}$ suspension were incubated in 96-well plates. The cells were treated with $20 \mu \mathrm{l}$ GCV at the concentrations of $10^{-2}, 10^{-1}, 1,10,10^{2}$, $10^{3} \mu \mathrm{g} / \mathrm{ml}$ for $72 \mathrm{~h}$ at $37^{\circ} \mathrm{C}$ in $5 \% \mathrm{CO}_{2}$ incubator. $\mathrm{SKOV}_{3} /$ tk-MCP-1 and $\mathrm{SKOV}_{3} /$ neo seeded by same way was added GCV $(1.0 \mu \mathrm{g} / \mathrm{ml}, 0.1 \mu \mathrm{g} / \mathrm{ml})$ incubated for 24, 48, 72 and $96 \mathrm{~h}$ to detect time toxicity of GCV. $20 \mu \mathrm{l}$ Sodium Chloride was added to controls. The activity of the mitochondria, reflecting cellular growth and viability, was evaluated by measuring the optical density at $490 \mathrm{~nm}$ on microtiter plate reader.

We also detected the antitumor effect of human monocytes on gene modified ovarian cells by MTT: There were 3 experimental groups including $\mathrm{SKOV}_{3} /$ $\mathrm{MCP}-1, \mathrm{SKOV}_{3} / \mathrm{tk}-\mathrm{MCP}-1$ and $\mathrm{SKOV}_{3} /$ neo. Mononuclear cells were used as effectors, and tumor cells abovementioned were used as target. Cells were seeded in the 96-well plates at the density of $5 \times 10^{3}$ cells/well. Then mononuclear were added at different ratio of effector to target $(20: 1,10: 1,5: 1)$, incubated at $37^{\circ} \mathrm{C}$ in $5 \% \mathrm{CO}_{2}$ incubator for 4 days, cytotoxicity were determined.

The surviving rate of mixed tumor cell under the action of GCV only was determined by MTT. Briefly, there were 3 experimental groups (including $\mathrm{SKOV}_{3} / \mathrm{tk}, \mathrm{SKOV}_{3} / \mathrm{tk}$ $\mathrm{MCP}-1$ and $\mathrm{SKOV}_{3} /$ neo). The above cells infected by different gene at different proportion (100\%, 90\%, 70\%, 


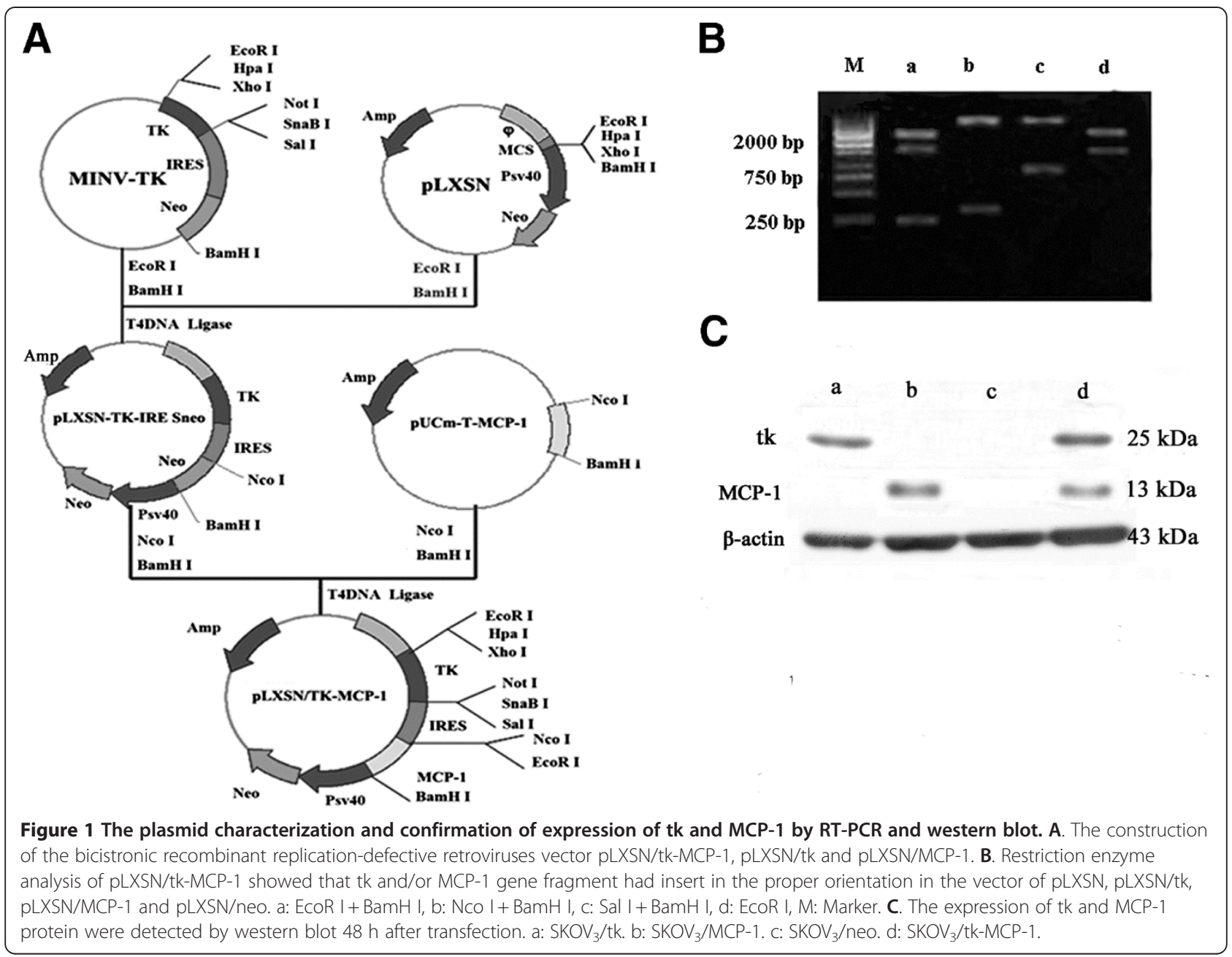

$50 \%, 30 \%, 10 \%, 0)$ were mixed with wild $\mathrm{SKOV}_{3}$, and then were added in $10 \mu \mathrm{g} / \mathrm{ml} \mathrm{GCV}$ The surviving rate of cells were determined by MTT incubated in 96-well plates for 4 days at $37^{\circ} \mathrm{C}$ in $5 \% \mathrm{CO}_{2}$ incubator.

Next we detect the surviving rate of mixed tumor cell under the action of GCV plus human monocytes by MTT. Each kind of cells and wild $\mathrm{SKOV}_{3}$ were seeded in 96-well plates as the same way. Then $5 \times 10^{4}$ human monocytes were added at the ratios of 10:1(effectors: target). All cells were incubated for 4 days at $37^{\circ} \mathrm{C}$ in $5 \% \mathrm{CO}_{2}$ incubator after supplied $10 \mu \mathrm{g} / \mathrm{ml} \mathrm{GCV}$. Cells without GCV were used as control group.

Detection of cell apoptosis rate, cell cycle and the expression of CD25 (IL-2R) and CD44v6 by flow cytometer: $\mathrm{SKOV}_{3} /$ tk, SKOV 3 /tk-MCP-1 and $\mathrm{SKOV}_{3} /$ neo were seeded in $25 \mathrm{~cm}$ flask. After cells adherenced, we added human monocytes at the ratios of 10:1(effectors: target) and $0.5 \mu \mathrm{g} /$ $\mathrm{ml} \mathrm{GCV}$, and then incubated cells for $48 \mathrm{~h}$ at $37^{\circ} \mathrm{C}$ in $5 \%$ $\mathrm{CO}_{2}$ incubator.

\section{Animal experiments}

The present study was approved by the local animal Care Committee and is in compliance with Chinese laws for animal protection. 6 to 8 weeks old, weight-matched female combined immune deficiency mice (C.B17/SCID) were purchased from Weitonglihua experimental animal limited company. Animals were housed in the animal facility of the Medical College of Shandong university of China. Enzyme-linked immunosorbent assay (ELISA) for the IgG of C.B17/SCIDs in serum was performed to eliminate immune leakage according to the manufacturer's protocol. Human mononuclear cells were isolated from human peripheral blood mononuclear cells by FicollHypaque discontiguous density gradient centrifugation technique and were re-suspended in fresh RPMI 1640 medium without NBS at a density of $8 \times 10^{7}$ cells $/ \mathrm{ml} .0 .5 \mathrm{ml}$ cell suspension was injected into abdominal cavity of per $\mathrm{C}$. B17/SCID for immunologic reconstitution. Twenty-four hours after celiac immunologic reconstitution, $\mathrm{SKOV}_{3} /$ 
neo, $\mathrm{SKOV}_{3} / \mathrm{tk}, \mathrm{SKOV}_{3} / \mathrm{MCP}-1$ and $\mathrm{SKOV}_{3} / \mathrm{tk}-\mathrm{MCP}-1$ cell lines were inoculated by intraperitoneal injection at a density of $2 \times 10^{7}$ cell/SCID. According to the cells inoculated, all experimental C.B17/SCIDs were divided into 4 groups, i.e. $\mathrm{SKOV}_{3} /$ neo, $\mathrm{SKOV}_{3} / \mathrm{tk}, \mathrm{SKOV}_{3} / \mathrm{MCP}-1$ and $\mathrm{SKOV}_{3} /$ tk-MCP-1 group (10 SCIDs/group). $\mathrm{SKOV}_{3} /$ neo group was used as control group and the rest groups were experimental groups. We injected GCV $75 \mathrm{mg} / \mathrm{kg} \cdot \mathrm{d}$ intraperitoneally for 5 days after tumor transplantation, then, observed the biologic characteristics of SCID, such as spirit, appetite and abdominal bulge.

The survival periods of 4 SCID mice selected randomly from each groups were recorded from being successfully transplanted human ovarian carcinoma cells to natural death. The rest 6 SCID mice of each groups were sacrificed as soon as the appearance of death in the control group.

The number of macrophages infiltrated the tumor sites was examined by flow cytometry. Briefly, monoplast suspension of tumor tissue was prepared by trituration. Cells were re-suspended in PBS at the density of $1 \times 10^{6}$ cells $/ \mathrm{ml}$ followed by addition of $10 \mu \mathrm{l}$ human CD14/PE (Pharmingen USA) antibody mixing thoroughly. After 30 min of activation away from light at $20^{\circ} \mathrm{C}-25^{\circ} \mathrm{C}$, flow cytometry was used to detect the amount of macrophages. The TNF- $\alpha$ protein level was analysised by western blot.

The cell apoptosis rate, cell cycle and the expression of CD25 (IL-2R) and CD44v6 in tumor cells were detected by flow cytometer.

\section{Statistical analysis}

The SPSS version 13.0 software was used for statistical analysis. Results were reported as means \pm standard deviation (SD). The statistical differences between group was assessed by q test. Kaplan-Meier survival curves were generated with the use of SPSS 13.0. Comparisons of median survivals were performed using log-rank tests. Alpha $(\alpha)$ level was set at 0.05 .

\section{Results}

\section{Confirmation of plasmid}

Restriction enzyme analysis of plasmid DNA showed that tk and MCP-1 gene fragment were inserted in the proper orientation in the vector of pLXSN named pLXSN/tk-MCP-1, so had pLXSN/tk, pLXSN/MCP-1 and $\mathrm{pLXSN} /$ neo (Figure 1-B).

\section{Packaging and transfection of pLXSN/tk, pLXSN/MCP-1, $\mathrm{pLXSN} / \mathrm{tk}-\mathrm{MCP}-1$ and $\mathrm{pLXSN}$ recombinantretroviral vector} The recombinant retroviral vectors including $\mathrm{pLXSN} / \mathrm{tk}$, pLXSN/MCP-1, pLXSN/tk-MCP-1 and pLXSN/neo, were transfected into retroviral packaging cell line PA317 by DOTAP, respectively. Stable retroviral vector-produced lines were generated by expanding the G418-resistant (>500 $\mu \mathrm{g} / \mathrm{ml}$ ) colonies, named PA317/tk (pLXSN/tk transferred), PA317/MCP-1 (pLXSN/MCP-1 transferred), PA317/tk-MCP-1(pLXSN/tk- MCP-1 transferred) and PA317/neo (pLXSN transferred) respectively. The supernatant containing the packaged retroviruses was harvested, filtered and titrated $4.5 \times 10^{5} \mathrm{CFU} / \mathrm{ml}-6.0 \times 10^{5} \mathrm{CFU} / \mathrm{ml}$ determined in $\mathrm{NIH} 3 \mathrm{~T} 3$ cells. $\mathrm{SKOV}_{3}$ cells were infected with the high titre recombinant retrovirus (pLXSN/tk, pLXSN/MCP-1, pLXSN/tk-MCP-1 and pLXSN/neo), while $\mathrm{SKOV}_{3}$ tansfected $\mathrm{pLXSN} /$ neo was used as the control group. Stable retroviral vector-produced cell lines were generated by expanding the G418-resistant $(600 \mu \mathrm{g} / \mathrm{ml})$ colonies, named $\mathrm{SKOV}_{3} /$ neo, $\mathrm{SKOV}_{3} / \mathrm{tk}, \mathrm{SKOV}_{3} / \mathrm{MCP}-1$ and $\mathrm{SKOV}_{3} /$ tk-MCP-1 respectively.

\section{Validation of tk and MCP-1 expression}

Western blot analysis demonstrated that MCP-1 protein was expressed in the $\mathrm{SKOV}_{3} / \mathrm{MCP}-1$ and $\mathrm{SKOV}_{3} /$ tk-MCP-1, and tk protein was expressioned in the $\mathrm{SKOV}_{3} /$ tk and SKOV 3 /tk-MCP-1 (Figure 1-C).

\section{Antitumor effect}

As shown in Figure 2-A, the viability of cells dosedependently reduced. GCV at the density of $10^{-2}-10^{3} \mu \mathrm{g} /$ $\mathrm{ml}$ had obvious antitumor effect on $\mathrm{SKOV}_{3} / \mathrm{tk}$ $\left(\mathrm{IC} 50: 2.24 \pm 0.23 \mu \mathrm{g} / \mathrm{ml}\right.$ ) and $\mathrm{SKOV}_{3} / \mathrm{tk}-\mathrm{MCP}-1$ (IC50: $2.06 \pm 0.31 \mu \mathrm{g} / \mathrm{ml})$. The IC50 value of $\mathrm{SKOV}_{3} / \mathrm{tk}$ and $\mathrm{SKOV}_{3} /$ tk-MCP-1 significantly dropped when compared to that of $\mathrm{SKOV}_{3} /$ neo $(P<0.05)$. There was no significant difference between $\mathrm{SKOV}_{3} / \mathrm{MCP}-1$ group and control groups $(P>0.05)$. Besides, the beginning cytotoxic time of $0.1 \mu \mathrm{g} / \mathrm{ml} \mathrm{GCV}$ and $1.0 \mu \mathrm{g} / \mathrm{ml} \mathrm{GCV}$ was both $48 \mathrm{~h}$, and the $96 \mathrm{~h}$ kill rate of $0.1 \mu \mathrm{g} / \mathrm{ml} \mathrm{GCV}$ and $1.0 \mu \mathrm{g} / \mathrm{ml} \mathrm{GCV}$ against $\mathrm{SKOV}_{3} /$ tk-MCP-1 was $40 \pm 2.19 \%$ and $90 \pm 4.55 \%$ respectively $(P<0.05)$ (Figure 2-B).

The antitumor effect of monocytes on ovarian cancer cells: The maximum lethality rate of $\mathrm{SKOV}_{3} / \mathrm{MCP}-1$ and $\mathrm{SKOV}_{3} /$ tk-MCP- 1 was $29 \pm 1.25 \%$ and $23 \pm 2.18 \%$ respectively, comparing to $1.8 \pm 0.64 \%$ of $\mathrm{SKOV}_{3} /$ neo $(\mathrm{P}<0.05)$. We found that the lethal effect of monocytes on tumor cells was effector-dependent, and the maximum lethality rate appeared at the ratio of 20:1(Figure 2-C).

The survival rate of $\mathrm{SKOV}_{3} /$ tk and $\mathrm{SKOV}_{3} /$ tk-MCP-1 incubating with $\mathrm{SKOV}_{3}$ in different ratio was evaluated after addition GCV or GCV plus monocytes (Figure 2-D). When $10 \mu \mathrm{g} / \mathrm{ml} \mathrm{GCV}$ was added, only $10 \%$ of $\mathrm{SKOV}_{3} / \mathrm{tk}$ or $\mathrm{SKOV}_{3} /$ tk-MCP-1 could kill about $40 \%$ of tumor cells. When the ratio of $\mathrm{SKOV}_{3} /$ tk or $\mathrm{SKOV}_{3} /$ tk-MCP-1 to $\mathrm{SKOV}_{3}$ was $50 \%$, there were about $80 \%$ of tumor cells killed. But cytotoxin did not appear with $\mathrm{SKOV}_{3} /$ neo $(P<0.05)$. Only $10 \%$ of tk-MCP- $1+\mathrm{GCV}+$ monocytes system could kill about $70 \%$ of tumor cells, while $40 \%$ of tk-MCP-1 + GCV + monocytes system could kill about $90 \%$ of tumor cells. 


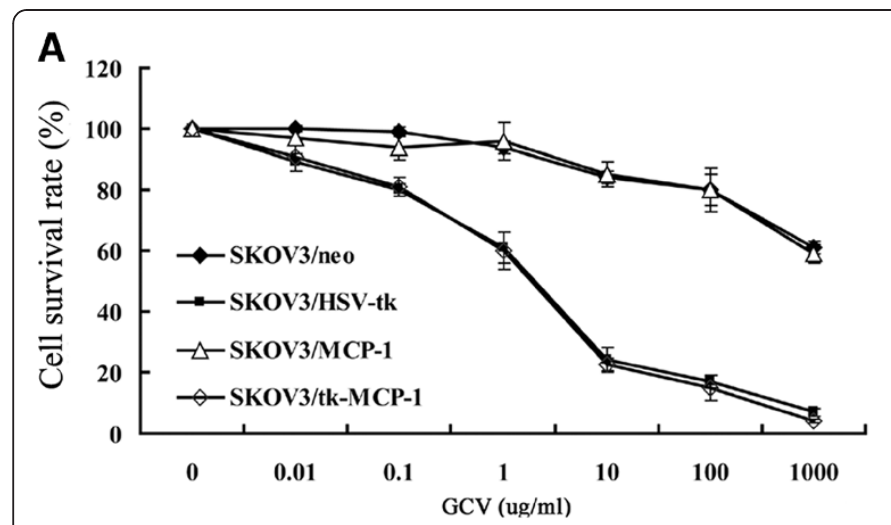

B
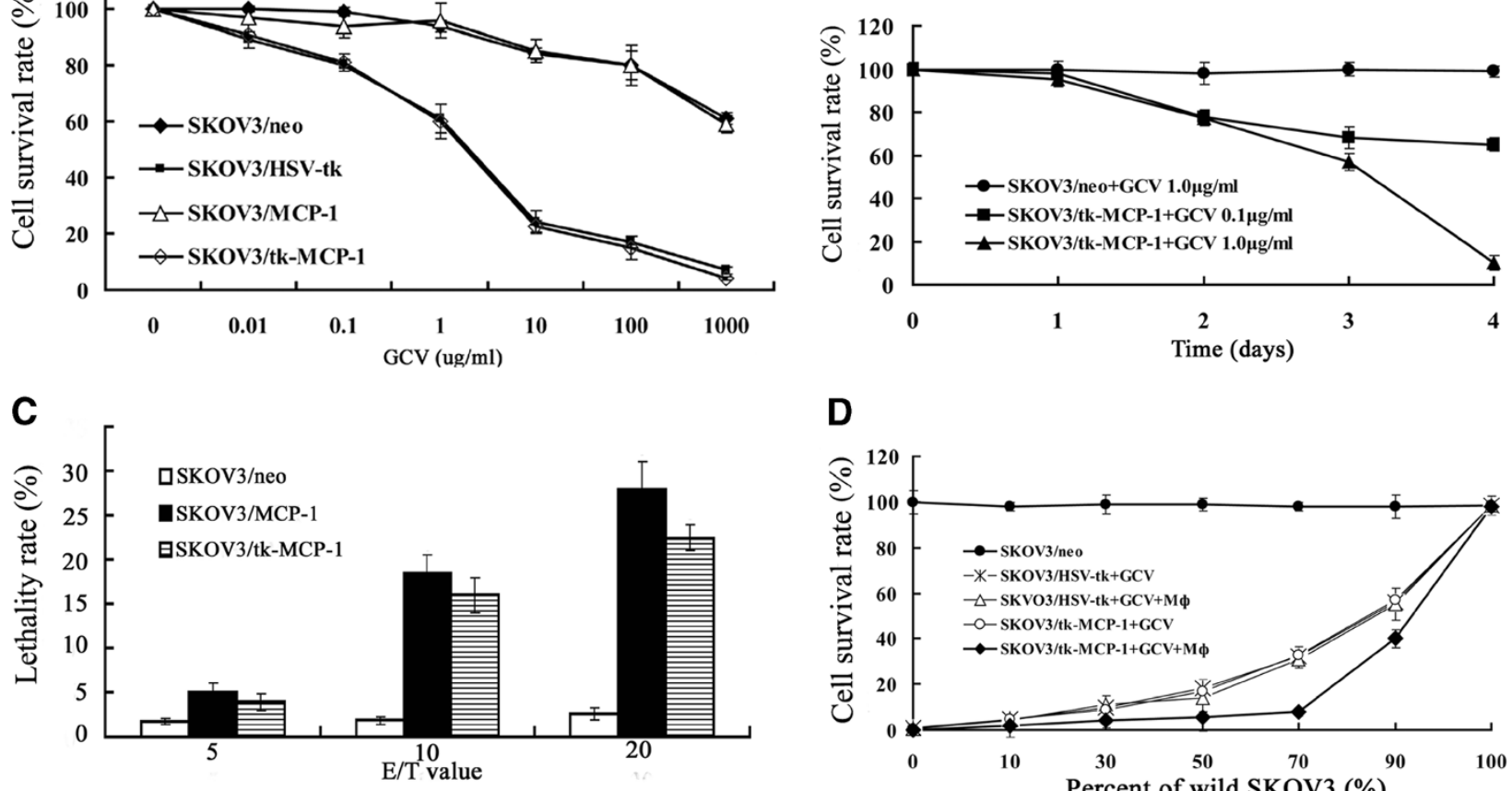

D

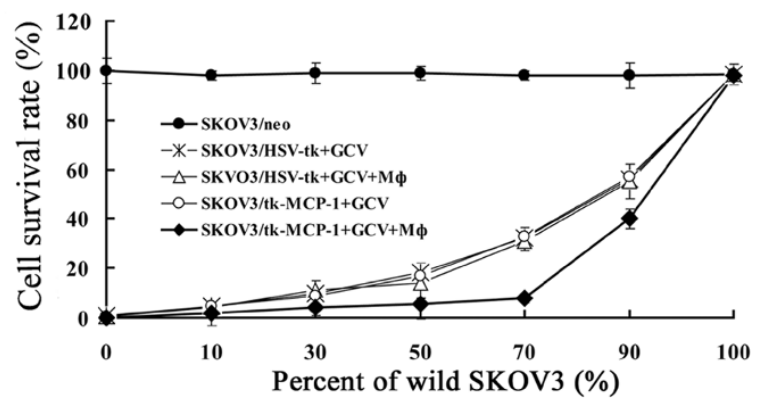

Figure 2 Antitumor effection. A: MTT assay of GCV on ovarian cancer cells. B: GCV at the density of $0.1 \mu \mathrm{g} / \mathrm{ml}$, the beginning cytotoxic was $48 \mathrm{~h}$ and $40 \%$ kill rate at $96 \mathrm{~h}$, however, the beginning cytotoxic was $48 \mathrm{~h}$ and $90 \%$ kill rate at $96 \mathrm{~h}$ when GCV at the density of $1.0 \mu \mathrm{g} / \mathrm{ml}$. C: Lethal effect of mononuclear macrophage on $\mathrm{SKOV}_{3} / \mathrm{MCP}-1$ and $\mathrm{SKOV}_{3} /$ tk-MCP-1 was determined by MTT assay. $\mathbf{D}$ : There is a synergistic antitumor effect when cooperated tk-MCP-1 + GCV system with mononuclear macrophage.

The result of flow cytometer showed that the apoptotic rate of $\mathrm{SKOV}_{3} / \mathrm{tk}-\mathrm{MCP}-1(13.48 \pm 1.01 \%)$ was obviously higher than those of $\mathrm{SKOV}_{3} / \mathrm{tk}(9.50 \pm 1.33 \%)$ and $\mathrm{SKOV}_{3} /$ neo $(2.19 \pm 0.56 \%) \quad(P<0.05), \quad \mathrm{S}$ phase of $\mathrm{SKOV}_{3} /$ tk $(38.31 \pm 1.67 \%)$ was lower than that of $\mathrm{SKOV}_{3} / \mathrm{tk}-\mathrm{MCP}-1$ $(52.92 \pm 1.78 \%)(P<0.05)$ (Table 1$)$.

The percentage of positive cell represents content of CD25 (IL-2r) or CD44v6 (Figure 3), CD25 of $\mathrm{SKOV}_{3} / \mathrm{tk}$ $(20.00 \pm 2.04 \%)$ and $\mathrm{SKOV}_{3} / \mathrm{tk}-\mathrm{MCP}-1 \quad(38.82 \pm 2.48 \%)$ was obviously higher than that of $\mathrm{SKOV}_{3} /$ neo $(8.73 \pm 1.65 \%)(P<0.05)$. CD25 of $\mathrm{SKOV}_{3} /$ tk-MCP-1 was significantly higher than that of $\mathrm{SKOV}_{3} / \mathrm{tk} \quad(P<0.05)$. $\mathrm{CD}_{4} 4 \mathrm{v} 6$ of $\mathrm{SKOV}_{3} /$ tk $(6.66 \pm 2.01 \%)$ and $\mathrm{SKOV}_{3} /$ tk-MCP-1 $(6.51 \pm 1.03 \%)$ was significant lower than that of control group $(40.74 \pm 3.58 \%)(P<0.01)$.

Table 1 Post-treatment apoptotic rate and cell cycle analysis $(\overline{\mathbf{x}} \pm \mathbf{s})$

\begin{tabular}{lrrc}
\hline & $\mathbf{S K O V}_{\mathbf{3}} / \mathbf{n e o}$ & SKOV $_{3} /$ tk & SKOV $_{\mathbf{3}}$ /tk-MCP-1 \\
\hline Apoptotic rate (\%) & $2.19 \pm 0.56$ & $9.50 \pm 1.33$ & $13.48 \pm 1.01$ \\
\hline GO/G1 (\%) & $53.90 \pm 1.66$ & $53.10 \pm 1.21$ & $40.28 \pm 1.11$ \\
\hline S (\%) & $19.34 \pm 0.65$ & $38.31 \pm 1.67$ & $52.92 \pm 1.78$ \\
\hline G/M (\%) & $26.76 \pm 1.01$ & $8.59 \pm 1.25$ & $6.80 \pm 1.11$ \\
\hline
\end{tabular}

Antitumor effects of recombinant gene in vivo

Forty SCIDs (IgG $<5 \mu \mathrm{g} / \mathrm{ml})$ were injected PBMC intraperitoneally. Three weeks later immune reconstruction was successfully established in SCID mouse (human IgG $>5 \mu \mathrm{g} / \mathrm{ml})$. The ratio of successful tumor transplantation was $100 \%$. The tumor was widespread in peritoneal cavity. The reduction of abdominal bulge and the improvement of spirit and appetite of tk-MCP-1group were greater than tk or MCP-1, and the condition of control group had no amelioration. The survival period of tkMCP-1 group was significantly longer than tk or MCP-1 group, followed by the control group $(35 \pm 2.94 \mathrm{~d}$, $25 \pm 2.16 \mathrm{~d}, 26 \pm 2.58 \mathrm{~d}$ and $15 \pm 3.16 \mathrm{~d}, P<0.05)$. There was no significant difference between tk and MCP-1 groups $(P>0.05)$ (Figure 4-F). The ovarian tumors of the tk-MCP-1 group shrank significantly, followed by the tk or MCP-1 group. However, the tumor of the control group was still widespread in peritoneal cavity and cavitas pelvis There was no significant difference between tk and MCP-1 groups $(P>0.05)$ (Figure $4 \mathrm{~A}-\mathrm{E})$. As shown in Figure 5 and Table 2, flow cytometry examination revealed that the number of macrophages infiltrated the tumor tissues in the control group, tk or $\mathrm{MCP}-1$ group and tk-MCP-1 group increased in order $(P<0.05)$, so did 


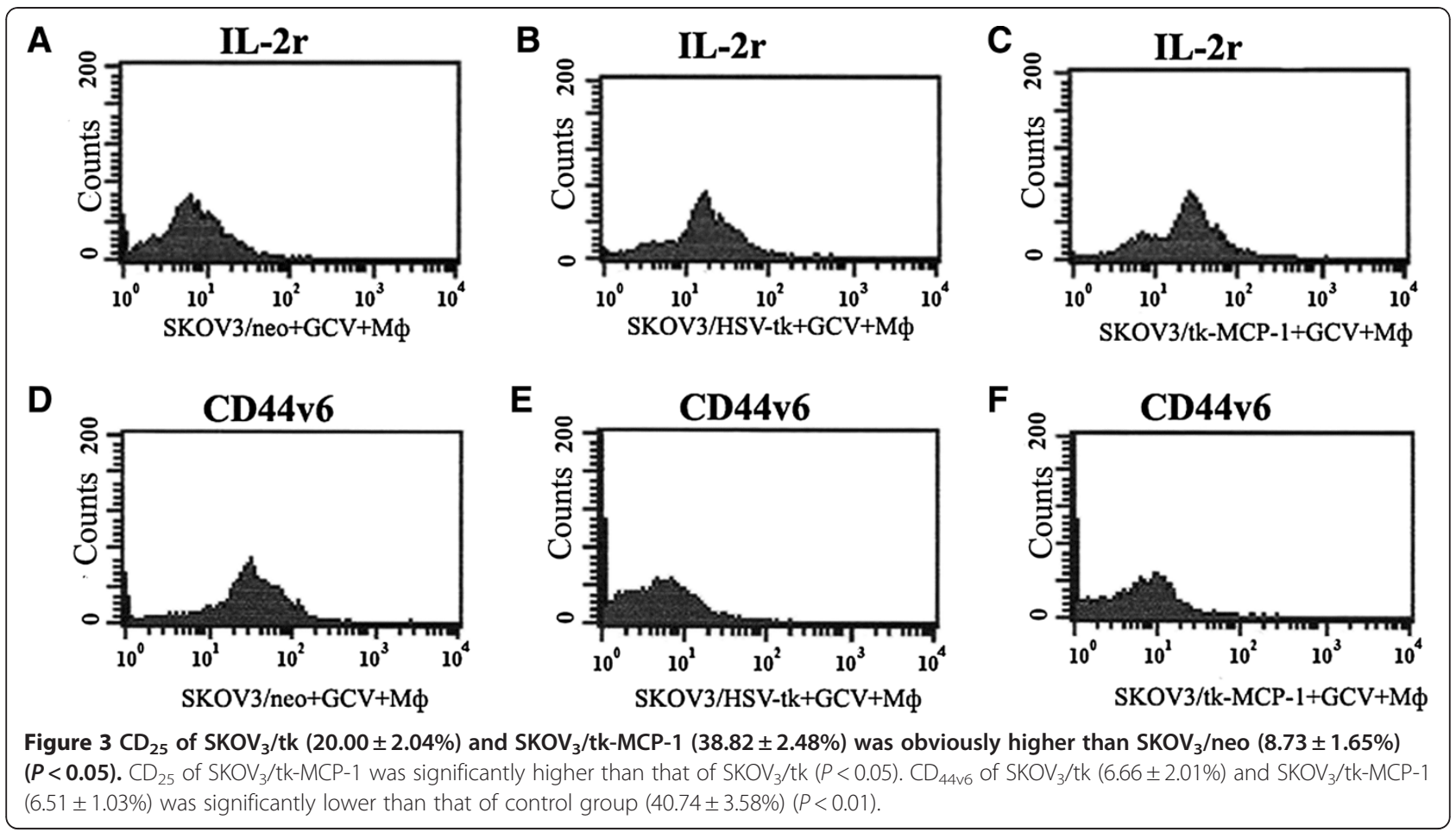

TNF- $\alpha$ protein level from the activated microphages. There was no significant difference between tk and MCP-1 groups $(P>0.05)$.

\section{Discussion}

It is clear that expression of a single transgene is unlikely to be sufficient to eradicate ovarian cancer that is diagnosed late in disease progression. Many studies have demonstrated that HSV-tk combined with cytokine therapy followed by GCV has a higher chance of success [13-18]. MCP-1 (CCL2) has been successfully used to treat hepatocellular carcinoma by recombinant adenovirus vector (rAd) s expressing with HSV-tk [19]. Because several preclinical studies have demonstrated that genotoxic potential is not identical among all retroviral vector systems [20], and IRES could enable two different gene expressed simultaneously [21], we constructed pLXSN/tk-MCP-1 which co-expresses tk and MCP-1, and assessed the antitumor effect of pLXSN/tk-MCP-1 on ovarian cancer.

MCP-1 plays a crucial role in tumor tissue inflammatory response by activating and inducing the infiltration of macrophages, and in the regulation of adhesion factors expression which causes the contact ot macrophages with tumor cells. Once the effector cells get close to target cells, macrophages present the effect of antitumor by swallowing and killing pathogen, corpus alienum, senile and mutant cells, participating in nonspecific immune reaction and specific immunity, dealing with antigenic properties and presenting antigenic information to $\mathrm{T}$ or $\mathrm{B}$ lymphocyte
[22-24]. Yamashiro et al. [25] found that the increasing amount of activated peripheral blood monouclear cells transfected MCP-1 gene infiltrating in tumor could restrain the growth of tumor. The present study suggested that MCP-1 could activate human mononuclear macrophage and carries a role in antitumor reaction, but the growth of tumor cells in control group was scarcely refrained. The more the effector cells, the stronger the tumoricidal effect of mononuclear macrophage was. Here our data provided strong evidence that MCP-1 had the antitumor reaction by activating mononuclear macrophage.

Bystander effect plays an important role in suicide gene therapy of tumor. Many studies have demonstrated that bystander effect might be due to immunization. Ramesh et al. [26] confirmed that the integrity of host immune was essential for suicide gene therapy. They performed RT-PCR after HSV-tk + GCV treatment and found the release of cytokines (TNF- $\alpha$, IL-1, IL-6, IFN- $\alpha$ and GM-CSF mRNA) consistently increased [27].

Immunohistochemical analysis for tumor tissue after HSV-tk/GCV treatment showed a great quantity of CD4 ${ }^{+}$, $\mathrm{CD}^{+}$lympholeukocyte recruiment. Gagandeep et al. [28] found that many immunocells infiltrated in tumor after HSV-tk + GCV therapy and cytokines released to cause hemorrhagic necrosis of tumor. The externalization of these cytokines depended on tumor cytotoxic effect and revoked up-regulation of immunological regulators such as MHC, B7 and ICAM-1. Accordingly, the mechanism of bystander effect depends on the transition of tumor 
A

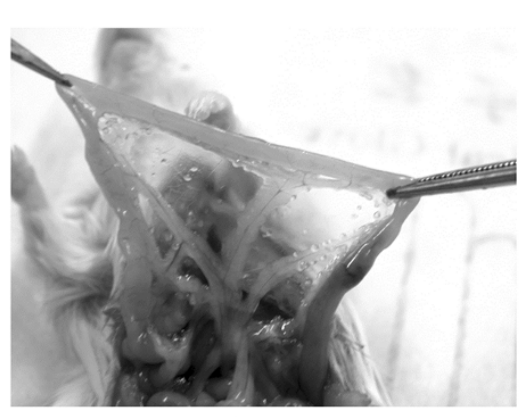

normal SCID

C

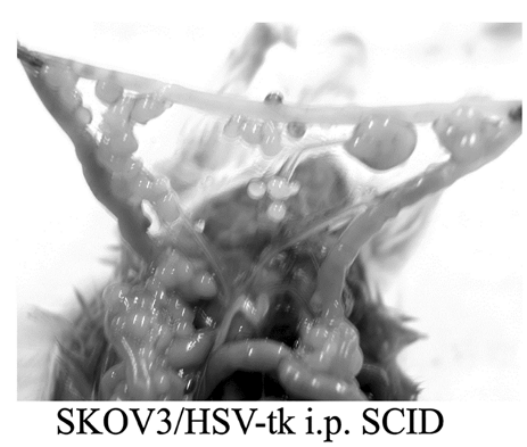

E

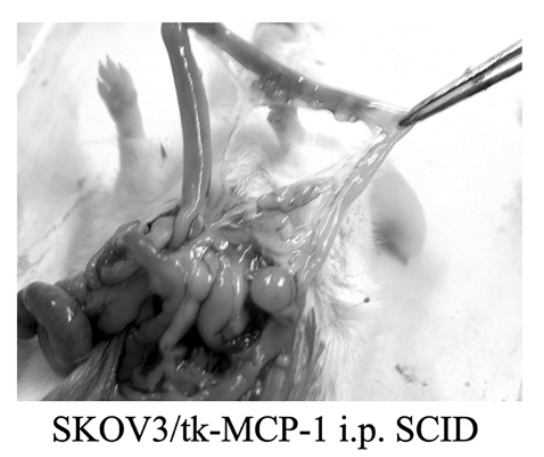

B

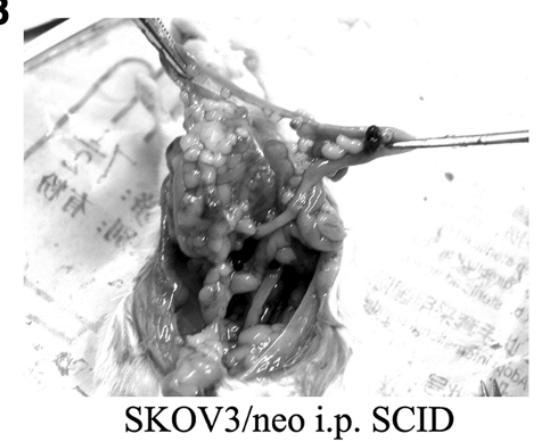

D

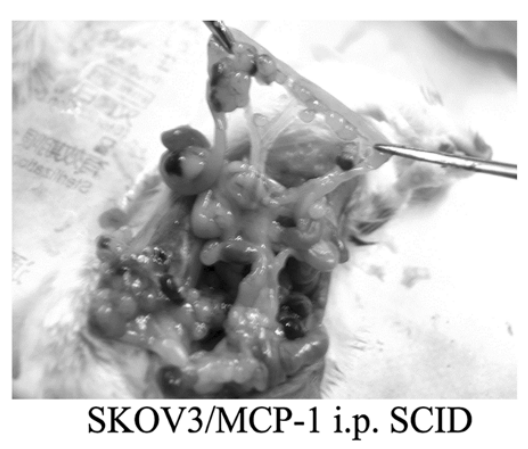

$F$

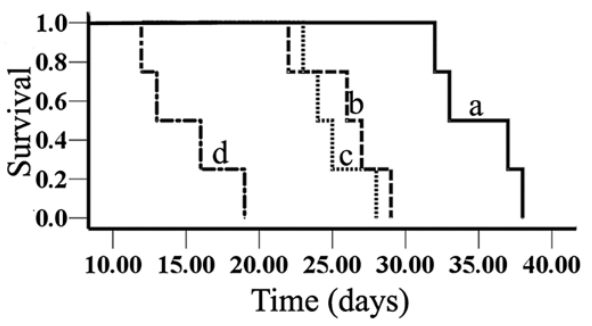

Figure 4 A-E. The ovarian tumors of the tk-MCP-1 group shrank significantly, followed by the tk or MCP-1 group. However, the tumor of the control group was still widespread in peritoneal cavity and cavitas pelvis. F. Kaplan-Meier survival analysis of mice intraperitoneally transplanted with diverse tumor cells. a. SKOV 3 /tk-MCP-1 b. SKOV $3 /$ MCP-1 c. SKOV $/$ tk d. SKOV $/$ neo.

microenvironment from immune suppression to immune activated state which initiates anti-tumor effect of immunal inflammatory system.

The use of cytokine gene therapy combined with suicide gene/prodrug can enhance bystander effect by reinforcing immune function. Chen et al. [29] injected recombined adenovirus expressed both IL- 2 gene and HSV-tk gene to colon carcinoma model with hepatic metastasis, and found that the link of tk gene and IL-2 possess was more sufficient than individual gene therapy.

We demonstrated that the therapy of a combining suicide gene (HSV-tk and MCP-1) significantly improved the antitumor efficiency on $\mathrm{SKOV}_{3}$ cells by bicistronic recombinant replication-defective retroviruses vector $\mathrm{pLXSN} / \mathrm{tk}$ MCP-1 constructed in our lab. The bicistronic pLXSN co-expressing tk and MCP-1 linked by a bicistronic unit including poliomyelitis virus IRES was designed by proteinaceous translation initiation model inside chain of eukaryotic cell. The single upstream promoter can transcribe the same mRNA from two genes, and then the gene in the upstream is translated in eukaryocyte capdependent manner, while the downstream gene can be translated and expressed under the control of IRES in cap-independent manner, avoiding the influence on expression of the two genes at the regulation level of transcription.

The maximum concentration of MCP-1 and the result of chemotactic index of MCP-1-mediated migration showed that $\mathrm{SKOV}_{3} / \mathrm{tk}-\mathrm{MCP}-1$ could secrete $\mathrm{MCP}-1$ possessed chemotactic activity. Furthermore, our study showed a 


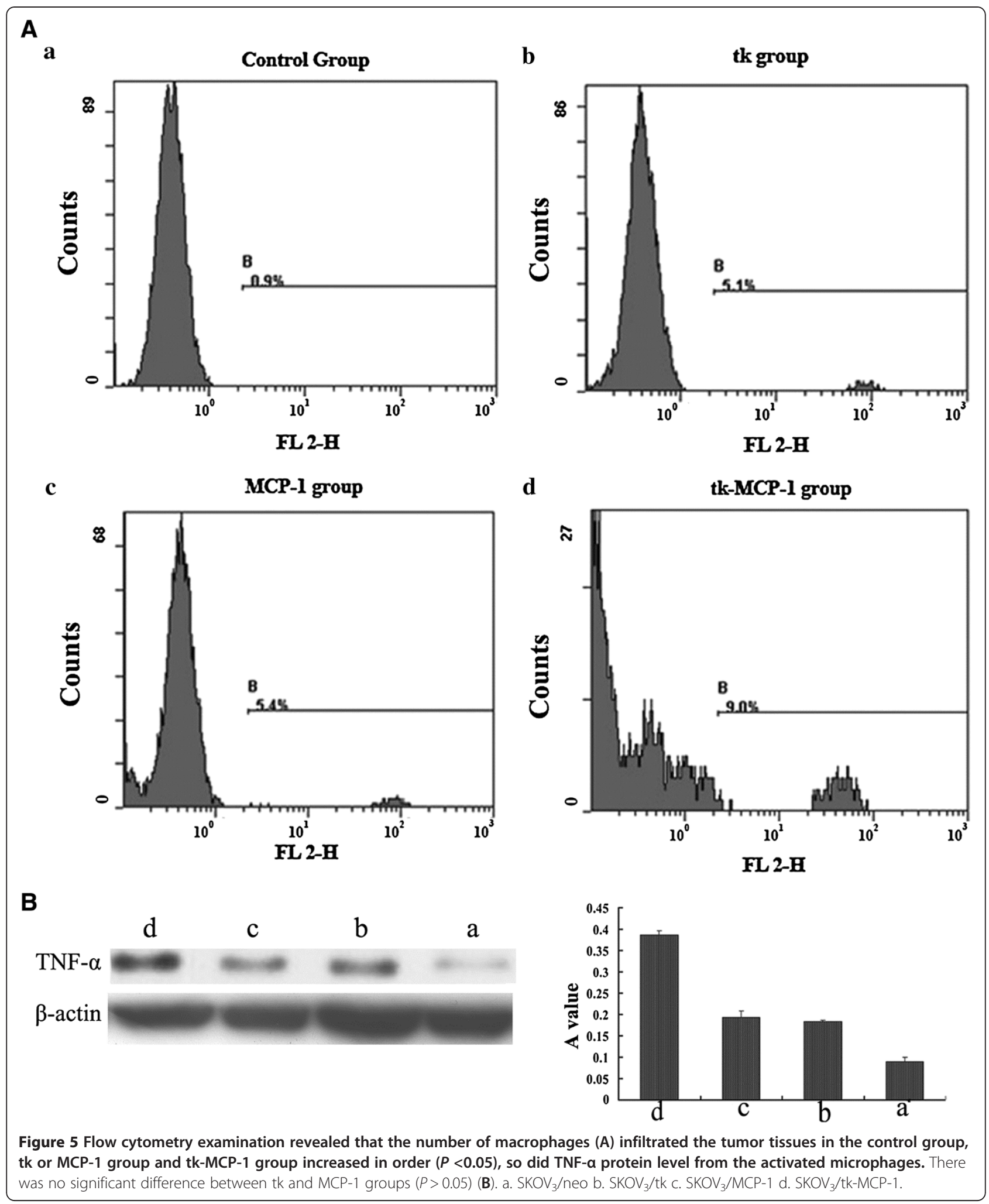

strong bystander effect was observed in the system of $\mathrm{SKOV}_{3} /$ tk-MCP-1+GCV. MCP-1 is one of the major chemoattractants for mononuclear macrophage which can directly eradicate tumor cells, the importance is MCP-1 significantly induced a low survival rate when transduced cells and untransduced cells are cultured together in 
Table 2 Mean Percent of macrophages in each group

\begin{tabular}{ll}
\hline Groups & Percent of macrophages $(\%)(\overline{\mathbf{x}} \pm \mathbf{s})$ \\
\hline tk-MCP-1 & $8.70 \pm 0.35$ \\
\hline MCP-1 & $5.20 \pm 0.28$ \\
\hline HSV-tk & $4.90 \pm 0.24$ \\
\hline The control group & $0.90 \pm 0.25$ \\
\hline
\end{tabular}

specific ratios as a immuno-modulator. Boosted bystander effect by immunal inflammatory system showed 10\% tk + can induce a $70 \%$ tumor cells death rate. Combined HSV-tk with MCP-1 gene therapy is a powerful approach for the treatment of ovarian cancer. They not only could play their antitumor role respectively, but also could creat synergistic action which could enhance the anti-tumor immune reactions. Many immune effector cells aggregate to tumor site via the expression of MCP-1 activity and provoke nonspecific immune reaction and specific immunity, not only boosting the cytotoxic effect of GCV but also enhancing immune reaction to reinforce the bystander effect.

In order to explore the synergic antineoplastic mechanism and the influence on tumorous biological behavior of combined HSV-tk and MCP-1 gene, we investigated apoptosis and cell cycle. The results indicated that with the depressant effect of treatment on ovarian cells, FCM emerged manifest apoptotic peak, and that the proportion of S stage phase in cell cycle significantly increased at the same time compared with the control group. We also detected that the apoptosis rate of $\mathrm{SKOV}_{3}$ caused by HSV-tk-MCP-1 + GCV $(13.48 \pm 1.01 \%)$ was significant higher than that of HSV-tk + GCV $(9.50 \pm 1.33 \%)$. Similarly, the proportion of $S$ stage of the former markedly increased than the latter.

These studies open the possibility that the prodrug GCV can blockage the cell cycle at $\mathrm{S}$ stage. The fact that the expression of CD25 significant raised after $\mathrm{SKOV}_{3}$ transfected tk-MCP-1 gene detected by FACS suggests that the immunogenicity of tumor cells may be enhanced after the treatment of combined tk and MCP-1 gene therapy. A study showed that the abnormal expression of adhesion molecule of cell surface CD44 and its var CD44v6 is closely related to infiltration, metastasis and dysprognosis of malignancy [30,31]. We also demonstrated that the expression of CD44v6 was significantly lower after the administration of GCV on tumor cells successfully transfected $\mathrm{SKOV}_{3} / \mathrm{tk}$ and $\mathrm{SKOV}_{3} / \mathrm{tk}-\mathrm{MCP}-1$ gene, which suggests that suicide gene therapy may retroconverse the infiltration, metastasis of malignant cells and the expression of MCP-1 has no significant effect.

Freeman and colleagues [32] reported that suicide gene therapy could shift tumorous microenvironment from immune suppression to immunostimulation in order to initiate antitumor effect by inflammation, indicating that bystander effect relies in part on an intact immune system following tk/GCV gene therapy. We used SCID mouse as tumor vehicle, which had defect in both cellular and humoral immune function, to explore the antitumor mechanism of human immunal system. SCID mouse is an ideal preclinical empirical animal model because it can either load human tumor or be immunal functional reconstructed by human immunocyte. In this study, $\mathrm{SKOV}_{3} / \mathrm{tk}$, $\mathrm{SKOV}_{3} / \mathrm{MCP}-1$ or $\mathrm{SKOV}_{3} /$ tk-MCP-1 cell line was intraperitoneally transplanted after immune reconstruction being successfully established in SCID mouse 3 weeks after intraperitoneally transplantation of PBMC. The tumor was widespread in peritoneal cavity, mainly in diaphragm, liver and mesentery. We demonstrated that tk-MCP-1 fusion gene had significantly tumoricidal effect in vivo partly depending on the effector of TNF- $\alpha$ from the activated of mononuclear macrophages induced by MCP-1.

\section{Conclusions}

In conclusion, our data suggest that combined suicide gene therapy with immune gene therapy generates significantly stronger therapeutic antitumor effects by different mechanism and distinct link. This research provided sound evidence for preclinical research of ovarian carcinoma treatment, and might become the theoretical of a novel therapeutic strategy.

\section{Competing interests}

The authors declare that they have no competing interests.

\section{Authors' contributions}

SHH, FNR and BHK made conception, designed and coordinated the study, carried out data interpretation, and drafted the manuscript; PZ and $\mathrm{HZ}$ participated in the conception and design of the study, and participated in drafting of manuscript; $L J$ participated in the design of the study and performed the statistical analysis; XQ and QFY conceived of the study, and participated in its design and coordination and helped to draft the manuscript. All authors read and approved the final manuscript.

\section{Acknowledgements}

The work was supported by the National Natural Science Foundations of China to Beihua Kong (NO. 30872738), Shandong Provincial Natural Science Foundation, China to Shuhui Hong (NO. ZR2009CL015), the Projects of Medical and Health Development of Shandong Province to Ping Zhang (NO. 2005JW2015), National Natural Science Foundations of China to Lin Jia (NO. 30901590), and Doctoral Fund of Shandong Province to Hui Zhang (NO. BS2009YY039).

\section{Author details}

'Department of Obstetrics and Gynecology, Qilu Hospital, Shandong University, 107 Wenhuaxi Road, Ji'nan 250012, People's Republic of China. 2Department of Obstetrics and Gynecology, Affiliated Qianfoshan Hospital of Shandong University, 16766 Jingshi Road, Ji'nan 250014, People's Republic of China. ${ }^{3}$ Department of Obstetrics and Gynecology, The Second Hospital of Shandong University, 247 Beiyuan Street, Ji'nan 250033, People's Republic of China. ${ }^{4}$ Department of Basic Medicine Science, Qilu Hospital, Shandong University, 107 Wenhuaxi Road, Ji'nan 250012, People's Republic of China. ${ }^{5}$ Department of Breast Surgery, Qilu Hospital, Shandong University, 107 Wenhuaxi Road, Ji'nan 250012, People's Republic of China. 
Received: 25 October 2011 Accepted: 1 March 2012

Published: 12 September 2012

\section{References}

1. Seibaek L, Petersen LK, Blaakaer J, Hounsgaard L: Symptom interpretation and health care seeking in ovarian cancer. BMC Womens Health 2011, 11:31.

2. Salzman J, Marinelli RJ, Wang PL, Green AE, Nielsen JS, Nelson BH, et al: ESRRA-C11orf20 Is a Recurrent Gene Fusion in Serous Ovarian Carcinoma. PLOS Biol 2011, 9:e1001156.

3. Agarwal R, Kaye SB: Ovarian cancer: strategies for overcoming resistance to chemotherapy. Nat Rev Cancer 2003, 3:502-516.

4. Huber BE, Richards CA, Austin EA: Virus-directed enzyme/prodrug therapy (VDEPT). Selectively engineering drug sensitivity into tumors. Ann N Y Acad Sci 1994, 716:104-14. discussion 40-43.

5. Marais R, Spooner RA, Light Y, Martin J, Springer CJ: Gene-directed enzyme prodrug therapy with a mustard prodrug/carboxypeptidase G2 combination. Cancer Res 1996, 56:4735-4742.

6. Lv SQ, Zhang KB, Zhang EE, Gao FY, Yin CL, Huang CJ, et al: Antitumor efficiency of the cytosine deaminase/5-fluorocytosine suicide gene therapy system on malignant gliomas: an in vivo study. Med Sci Monit 2009, 15:BR13-BR20.

7. Finocchiaro LM, Riveros MD, Glikin GC: Cytokine-enhanced vaccine and suicide gene therapy as adjuvant treatments of metastatic melanoma in a horse. Vet Rec 2009, 164:278-279.

8. Xu B, Liu ZZ, Zhang J, Zong XL, Cai JL: Effects of recombinant adenovirusmediated double suicide genes on implanted human keloid: experiment with athymic mice. Zhonghua yi xue za zhi 2008, 88:3428-3431.

9. Elshami AA, Saavedra A, Zhang H, Kucharczuk JC, Spray DC, Fishman Gl, et al: Gap junctions play a role in the 'bystander effect' of the herpes simplex virus thymidine kinase/ganciclovir system in vitro. Gene Ther 1996, 3:85-92.

10. Kianmanesh AR, Perrin H, Panis Y, Fabre M, Nagy HJ, Houssin D, et al: A "distant" bystander effect of suicide gene therapy: regression of nontransduced tumors together with a distant transduced tumor. Hum Gene Ther 1997, 8:1807-1814.

11. Yoshimura T, Leonard EJ: Human monocyte chemoattractant protein-1: structure and function. Cytokines 1992, 4:131-152.

12. Carr MW, Roth SJ, Luther E, Rose SS, Springer TA: Monocyte chemoattractant protein 1 acts as a T-lymphocyte chemoattractant. Proc Natl Acad Sci U S A 1994, 91:3652-3656.

13. Tsuchiyama T, Nakamoto Y, Sakai Y, Mukaida N, Kaneko S: Optimal amount of monocyte chemoattractant protein-1 enhances antitumor effects of suicide gene therapy against hepatocellular carcinoma by M1 macrophage activation. Cancer Sci 2008, 99:2075-2082.

14. lida N, Nakamoto Y, Baba T, Kakinoki K, Li YY, Wu Y, et al: Tumor cell apoptosis induces tumor-specific immunity in a CC chemokine receptor 1- and 5-dependent manner in mice. J Leukoc Biol 2008, 84:1001-1010.

15. Hanari N, Matsubara H, Hoshino I, Akutsu Y, Nishimori T, Murakami K, et al: Combinatory gene therapy with electrotransfer of midkine promoterHSV-TK and interleukin-21. Anticancer Res 2007, 27:2305-2310.

16. Faneca H, Cabrita AS, Simoes S: Pedroso de Lima MC. Evaluation of the antitumoral effect mediated by IL-12 and HSV-tk genes when delivered by a novel lipid-based system. Biochim Biophys Acta 2007, 1768:1093-1102

17. Majumdar AS, Zolotorev A, Samuel S, Tran K, Vertin B, Hall-Meier M, et al: Efficacy of herpes simplex virus thymidine kinase in combination with cytokine gene therapy in an experimental metastatic breast cancer model. Cancer Gene Ther 2000, 7:1086-1099.

18. Barton KN, Stricker H, Elshaikh MA, Pegg J, Cheng J, Zhang Y, et al: Feasibility of adenovirus-mediated hNIS gene transfer and 1311 radioiodine therapy as a definitive treatment for localized prostate cancer. Mol Ther J Am Soc Gene Ther 2011, 19:1353-1359.

19. Tsuchiyama T, Kaneko S, Nakamoto Y, Sakai Y, Honda M, Mukaida N, et al: Enhanced antitumor effects of a bicistronic adenovirus vector expressing both herpes simplex virus thymidine kinase and monocyte chemoattractant protein-1 against hepatocellular carcinoma. Cancer Gene Ther 2003, 10:260-269.

20. Nowrouzi A, Glimm H, von Kalle C, Schmidt M: Retroviral vectors: post entry events and genomic alterations. Viruses 2011, 3:429-455.
21. Zhang Z, Huang Y, Newman K, Gu J, Zhang X, Wu H, et al: Reexpression of human somatostatin receptor gene 2 gene mediated by oncolytic adenovirus increases antitumor activity of tumor necrosis factor-related apoptosis-inducing ligand against pancreatic cancer. Clin Cancer Res 2009, 15:5154-5160.

22. Jiang Y, Beller DI, Frendl G, Graves DT: Monocyte chemoattractant protein1 regulates adhesion molecule expression and cytokine production in human monocytes. J Immunol 1992, 148:2423-2428.

23. Arnaout MA: Structure and function of the leukocyte adhesion molecules CD11/CD18. Blood 1990, 75:1037-1050.

24. Fidler IJ: Macrophage therapy of cancer metastasis. CIBA Found Symp 1988, 141:211-222.

25. Yamashiro S, Takeya M, Nishi T, Kuratsu J, Yoshimura T, Ushio Y, et al: Tumor-derived monocyte chemoattractant protein-1 induces intratumoral infiltration of monocyte-derived macrophage subpopulation in transplanted rat tumors. Am J Pathol 1994, 145:856-867.

26. Ramesh R, Munshi A, Marrogi AJ, Freeman SM: Enhancement of tumor killing using a combination of tumor immunization and HSV-tk suicide gene therapy. Int J Cancer 1999, 80:380-6.

27. Freeman SM, Ramesh R, Shastri M, Munshi A, Jensen AK, Marrogi AJ: The role of cytokines in mediating the bystander effect using HSV-TK xenogeneic cells. Cancer Lett 1995, 92:167-174.

28. Gagandeep S, Brew R, Green B, Christmas SE, Klatzmann D, Poston GJ, et al Prodrug-activated gene therapy: involvement of an immunological component in the "bystander effect". Cancer Gene Ther 1996, 3:83-88.

29. Chen SH, Kosai K, Xu B, Pham-Nguyen K, Contant C, Finegold MJ, et al: Combination suicide and cytokine gene therapy for hepatic metastases of colon carcinoma: sustained antitumor immunity prolongs animal survival. Cancer Res 1996, 56:3758-3762.

30. Yamaguchi A, Goi T, Seki K, Ohtaki N, Maehara M, Kobayashi T, et al: Clinical significance of combined immunohistochemical detection of CD44v and sialyl LeX expression for colorectal cancer patients undergoing curative resection. Oncology 1998, 55:400-403.

31. Gotoda T, Matsumura Y, Kondo H, Saitoh D, Shimada Y, Kosuge T, et al: Expression of CD44 variants and its association with survival in pancreatic cancer. Jpn J Cancer Res 1998, 89:1033-1040.

32. Freeman SM, Ramesh $R$, Marrogi AJ: Immune system in suicide-gene therapy. Lancet 1997, 349:2-3.

doi:10.1186/1756-9966-31-74

Cite this article as: Hong et al.: Enforced effect of tk-MCP-1 fusion gene in ovarian cancer. Journal of Experimental \& Clinical Cancer Research 2012 $31: 74$.

\section{Submit your next manuscript to BioMed Central and take full advantage of:}

- Convenient online submission

- Thorough peer review

- No space constraints or color figure charges

- Immediate publication on acceptance

- Inclusion in PubMed, CAS, Scopus and Google Scholar

- Research which is freely available for redistribution 